\title{
A PORTRAIT OF THE SAKINAH FAMILY IN MANUSCRIPT TEXTS BY WOMEN SCHOLARS FROM THE PESANTREN
}

\author{
Samsul Arifin, Ummi Khairiyah, Minhaji \\ Ibrahimy University, Situbondo, Indonesia \\ E-mail: syamsulahasan@ibrahimy.ac.id
}

\begin{abstract}
The formation of the personality characteristics of a married couple is very important and decisive inthinking and acting in building a sakinah household. Sakinah will appear in the calmness of the heart and the clarity of their minds. The scholars, including women scholars from the pesantren have written about it. The purpose of this paper is to uncover and describe the ideal quality of the personality of a married couple in the eyes of women scholars from the pesantren. This article is interesting, because so far many books on household written by male scholars, not female scholars, so it tends to be paternalistic. This paper is useful for the development of Marriage Counseling science based on local pesantren wisdom. The focus of this paper is the portrait of the quality of the personality of a married couple in reaching a sakinah family in the book Zadu Az-Zaujayn (a reinterpretation of the book of Uqud al-Lujjayn ) by Ibu Nyai Zainiyah As'ad, Pondok Pesantren Salafiyah Syafi'iyah Sukorejo Situbondo from the perspective of marriage counseling. This research method uses Gadamer's hermeneutic approach. The results showed, married couples should have the quality of personality that has knowledge (about some rights and obligations, fiqh of women, and the ability to educate children), gracefully when bitter experiences (sabar), affection, acceptance of life as is (ridha and ikhlas), and create a good impression of their partner (self presentation). The focus of marriage counseling adhered to by the pesantren is directed at the improvement and development of the quality of the personality of a married couple rather than the problems in the marriage itself. If a married couple has a good personality then problems in a marriage can be solved by themselves. That personality will radiate in thinking and acting in everyday life to create a sakinah family.
\end{abstract}

Keywords: Zadu Az-Zaujayn; personality; sakinah

Abstrak. Pembentukan karakteristik kepribadian pasangan menikah sangat penting dan menentukan dalam berpikir dan bertindak dalam membangun rumah tangga sakinah. Sakinah akan muncul dalam ketenangan hati dan kejernihan pikiran mereka. Para cendekiawan, termasuk cendekiawan perempuan dari pesantren telah menulis tentang itu. Tujuan dari makalah ini adalah untuk mengungkap dan menggambarkan kualitas ideal kepribadian pasangan yang sudah menikah di mata ulama perempuan dari pesantren. Artikel ini menarik, karena selama ini banyak buku tentang rumah tangga yang ditulis oleh sarjana laki-laki, bukan sarjana perempuan, sehingga cenderung paternalistik. Makalah ini bermanfaat untuk pengembangan ilmu Konseling Perkawinan berdasarkan kearifan lokal pesantren. Fokus dari makalah ini adalah potret kualitas kepribadian pasangan yang sudah menikah dalam mencapai keluarga sakinah dalam buku Zadu Az-Zaujayn (reinterpretasi buku Uqud al-Lujjayn) oleh Ibu Nyai Zainiyah As'ad, Pondok Pesantren Salafiyah Syafi'iyah Sukorejo Situbondo dari perspektif konseling perkawinan. Metode penelitian ini menggunakan pendekatan hermeneutik Gadamer. Hasil penelitian menunjukkan, pasangan suami istri harus memiliki kualitas kepribadian yang memiliki pengetahuan (tentang beberapa hak dan kewajiban, fiqh perempuan, dan kemampuan untuk mendidik anak), anggun ketika pengalaman pahit (sabar), kasih sayang, penerimaan hidup apa adanya ( ridha dan ikhlas), dan menciptakan kesan yang baik tentang pasangan mereka (presentasi diri). Fokus konseling perkawinan yang dianut oleh pesantren diarahkan pada peningkatan dan pengembangan kualitas kepribadian pasangan menikah daripada masalah dalam pernikahan itu sendiri. Jika pasangan menikah memiliki kepribadian yang baik maka masalah dalam perkawinan dapat diselesaikan sendiri. Kepribadian itu akan terpancar dalam pemikiran dan tindakan dalam kehidupan sehari-hari untuk menciptakan keluarga sakinah.

Kata Kunci: Zadu Az-Zaujayn; Personal; sakinah

Permalink/DOI: https://doi.org/10.15408/harkat.v15i1.13441 


\section{Introduction}

One of the important studies for students in Islamic boarding schools (pesantren) in the book of Syarh Uqud al-Lujjayn fi Bayan Huqul az-Zawjayn by Imam Nawawi Banten (Muhammad Nawawi bin Umar al-Banteny alJawy). The book contains guidelines for married couples; which examines the obligations of husband and wife, the primacy of prayer at home for women, the prohibition of seeing the opposite sex, and the behavior of women. Uqud al-Lujjayn was enough to give influence to the Muslims in the life of the household and society. But even so, many kiai also disagree with the contents of the book because the position and role of men are too dominating (Bisri, 2001). Uqud al-Lujjayn tended to position the superiority of men, displaying

the nuances of traditionalism and sufism that were appropriate to the context of Indonesian society at the time (Muhammad, 2001). Islamic boarding school-based gender activists gathered in the "Forum Kajian Kitab Kuning (FK3). Marriage counseling that is extracted from the values of local wisdom is classified as rare. Some research on marriage counseling so far, usually only reveals the importance of marriage counseling and concepts of marriage counseling. For example, research by Dariyo (2005) about understanding the importance of counseling in helping to solve problems in marriage. Also the significance of marriage counseling in forming a sakinah family and several theoretical studies on marriage counseling (Atabik, 2015 and Zaini, 2015).

Journal of Konseling Religi Vol. 7 No. 2 of 2016 specifically discussing marriage counseling. Most of the writings contain the significance and conception of marriage counseling to form a sakinah family. For example, strategies and approaches to reach sakinah families and the conception of the Koran (Hasanah, 2016; Ahmad, 2016; and Basit, 2016;). Religious counseling also includes marriage counseling with other scientific approaches. For example with a sociological approach to the study of equality in the division of labor in Madurese (Mas'udi, 2016), genderbased (Ayurinanda, 2016), adversity quotient (Sakdiah, 2016), and humanistic counseling approaches (Mubasyaroh, 2016).

From some of these studies, there are no studies that review the personality portraits of candidates or married couples. Though psychologically, the personality is very determining both partners to think and act in building the household. Thus marriage counseling that examines personality development and that is extracted from local values, especially boarding schools is very important. Moreover, Islamic boarding schools are rich in local wisdom, including those related to counseling.

The purpose of this study is to uncover and describe the personality qualities of a married couple in reaching the ark of a sakinah household. This study discusses the views of pesantren mothers in fostering households. This article is interesting because so far many books about the household written by men so that it seems paternalistic. The focus of this paper is directed to describe the portrait of the quality of the personality of a married couple in reaching sakinah families in Zadu Az-Zaujayn. The author will review it from a counseling perspective; a science that helps people to overcome life's problems and boost their potential to grow and develop (growth and development) for the better (Arifin, 2018).

The theoretical framework in this study uses the perspective of indigenous counseling theories. Indigenous counseling presents an approach to the context (family, social, cultural, and ecological) content (meaning, values, and beliefs) explicitly included in the research design (Kim, 2010). Researchers also use the perspective of marriage counseling (marriage counseling), because it deals with married couples. Marriage 
counseling is counseling that is held as an educational method, a method of reducing emotional tension, a method to help married couples to solve problems and how to determine better patterns of problem-solving (Riyadi, 2013). This marriage counseling is in the process of forming and changing the mindset, attitude, willingness, and behavior of a married couple or future husband and wife. The focus of marriage counseling is a prospective husband or wife as a system that is experiencing premarital and marital problems (Sunarty, K \& Mahmud, A, 2016)

\section{Method}

This study uses a qualitative research method of a hermeneutic type. The hermeneutic approach used in this study adopts the Gadamer hermeneutic (2004). The hermeneutic approach is used to examine texts related to the personality of a married couple in the Zadu Az-Zaujayn book viewed from the perspective of marriage counseling. The steps of this research are to collect texts and reference sourcebooks, preinterpreted interpretations, and historical exposures.

\section{Result and Discussion}

Zadu Az-Zaujayn is one of the works of Nyai Zainiyah, the eldest daughter of KHR. As'ad Syamsul Arifin from Salafiyah Syafi'iyah Sukorejo Islamic Boarding School in Situbondo. Zadu Az- Zaujayn quoted from the book Uqud al-Lujjayn ; if the original book consists of five chapters, but in this book by Nyai Zai only two chapters; namely the article on the rights of a wife (husband's obligations) and the article on husband's rights (wife's obligations). The Zadu Az-Zaujayn book is also equipped with Indonesian-language poetry that includes the husband's manners, wife's manners, and about educating children. The thick 86 book is in
Arabic and is translated into Indonesian with pegon letters and Latin letters.

Nyai Zai was born in 1944 in the Jrangoan Islamic Boarding School, Omben, Sampang, Madura. He died on August 19, 2005 , in Sukorejo Situbondo. Nyai Zai is a caregiver for thousands of female students of the Salafiyah Syafi'iyah Sukorejo Islamic Boarding School in Situbondo. He is also the founder of the AlAs'adiyah Islamic Boarding School Balikeran Asembagus.

Aside from being an educator, Nyai Zai is also the author of several books. Among others: Syair Isra' Mi'raj (Madurese language that reveals the background and matters relating to the events of Israel Mi'raj); Dzikir Samawi (containing wired which he read at the Friday Legi recitation at the Balikeran Islamic Boarding School); Ighaatsah al- Lufhan (contains several prayers, wirid and munajat); 'Uddah alMu'minin (containing a collection of several prayers, dhikr, and qashidah);'Uddah alMu'minin (containing prayers and Madurese poems); Ad'iyyah wa Adzkar; Riyadl al- Jinan; and Doa Perjalanan ke Mekkah dan Madinah (Arifin, 2019).

Zadu Az-Zaujayn is a book taught by Nyai Zai to the female students, especially the cleric who is going to get married. So it's kind of a short course for students, prospective brides. According to Nyai Zai, many married couples fail to reach the Sakinah household because they do not know the conditions and manners in the marriage. Therefore, every candidate or husband and wife should develop ideal personality traits in their household. Among the portraits of the ideal personality of a prospective husband or wife, namely:

\section{Having knowledge}

According to Nyai Zai, a candidate or married couple must know their rights and obligations. The wife must have a good understanding of her rights which are at the 
same time an obligation of a husband. Likewise, the husband must understand what his rights are as well as the obligations of his wives.

The rights of a wife, among others: get a living that is food, clothing, and home. Nyai Zai expresses in the verses of his poem thus:

Hati-hatilah jadi suamilapa yang wajib terhadap istri

Dhahir dan batin wajib nafkahnya/terhadap istri jangan tinggalkan

Tempat tinggalnya disediakan/walaupun sewa atau pinjaman

Yakni tak wajib memilikkannya/dan wajib pula beri khadamnya

(Be careful being a husband / what is required of a wife

Dhahir and the conscience must make a living for his wife

The place of residence is provided / even if it is rent or loan

Namely not required to have it / and also must give servants)

While the rights of the husband, among others: teach and guide the wife and get obedience from the wife.

Para wanita tiap harinya/haruslah taat ke suaminya

Murka Allah dan malaikat/akan terpukul yang tidak tobat...

Tidaklah taat pada suami/inilah istri yang dimurkai

Pahala besar bagi si istri/yang sungguh taat pada suami...

Para suami wajib memberitahu/pada istrinya barang yang perlu

Barang yang baik dunia akhirat/biar tak jadi orang melarat...

Wajib membimbing bagi suami/agar tak salah untuk sang istri

(The women every day / must obey their husbands
The wrath of God and angels / will be struck down who do not repent ...

It is not obedient to the husband / this is the wrath of the wife

A great reward for the wife / truly devout husband ...

Husbands are obliged to inform their wives of the necessary items

Good things in the afterlife / not to be destitute ... Obligatory guidance for the husband / so that nothing is wrong for his wife)

Besides, the husband must know and teach about fiqh nisa'; fiqh related to female issues. For example, menstruation.

Wajib mengerti urusan haidhya / mulai datang sampai tuntasnya

Supaya tahu caranya shalat / yang wajib qadha biar tak lambat

Jika suami tidak mengert i/ pergilah tanya pada yang ngerti

Lalu ajarkan kepada istri / jika tak mampu cari sendiri

(Must understand menstruation / start coming to completion

To know how to pray / which must change so that it is not slow

If the husband does not understand/go ask the one who understands

Then teach it to your wife / if you are unable to find it yourself)

Another knowledge that a husband and wife must have is the ability to educate their children so that they have noble morals.

Bapak dan ibu sumbernya anak/ibu yang paling dekat ke anak

Sebab yang jadi baik rusaknya/si anak anak dari akhlaknya... 
Bapak dan ibu berhati-hati/mendidik anak jangan berhenti

Ke jalan baik akhlak yang mulia/sehingga jadi orang yang mulia

Didiklah anak jadi penolong/orang sengsara atau yang bingung

Bersopan santun pada yang tua/dan kasih sayang pada yang muda

Kepada anak beri didikan/laranglah serta perlu ingatkan

Banyak bertingkah atau

penakut/berburuk sangka serta pengecut

Ahli mengadu tiada guna/dengki takabur serta menghina

Pokok semua tingkahyang hina/jangan contohkan dan hindarkan

Semua anak ahli meniru/tingkah apapun senang ditiru

Ibarat cermin dia hatinya/terus melekat yang dilihatnya

Jadi penakut jika ditekan/barang sangkaan rasa sungguhan

Jika dihardik jadi sesalan/akal tertutup tak bisa jalan

(The father and mother are the children / mothers closest to the child

Because the damage / the children become good from their morals ...

Father and mother be careful / educate children do not stop

To the good path noble character / so that it becomes a noble person

Educate children to be helper / miserable or confused people

Good manners to the old / and affection for the young

To children give education / forbid and need to remind

Many acting or cowardly / prejudiced and cowardly
Expert pitting is useless / spiteful and insulting Principally all despicable behavior / do not model and avoid

All expert children imitate / whatever behavior likes to be imitated

Like a mirror he has his heart / clings to what he sees

So timid if pressed / real suspicion stuff

If rebuked so regret / closed mind cannot work)

\section{Sabar (Patient)}

According to Nyai Zai, patience must be owned by a married couple so that the household can continue to survive. Patients must also be possessed, especially if our partners do not feel pleasant. If we are patient with our partners, our lives will be glorious.

Nyai Zai suggested that we be patient and hold on to the pain, not to tell our partners weaknesses to others. Husband and wife must complement each other and cover the weaknesses of their partners; as the word of Allah (Surah Al-Baqarah: 187), "They (wives) are clothes for you (husbands) and you (wives) are clothes for them (wives)". If a wife is patient with her husband, he will get a rank like Siti Asiyah and Maryam.

Bila suami berwatak kejam/hanya menangis pedih dipendam

Di dalam surga dapat khasiat/pangkat sepadan Siti Asiyah...

Dia pemimpin para wanita/yang sama patuh pada suaminya

Tersebut pula Maryam namanya/di dalam surga pemimpin wanita

(If the husband has a cruel character / only cries bitterly buried

In heaven can benefit / rank of Siti Asiyah ‥

She is the leader of women who are equally obedient to her husband 
Also mentioned is Maryam's name / in the paradise of the female leader)

Sabar is a graceful attitude when a bitter experience is overtaken, manifests a rich attitude by hiding poverty in life, and still behaves well (Al- Qusyairi, 1998).

\section{Affection}

A married couple must have a loving personality. In the book of Zadu Az-Zaujayn quoted the words of the Prophet Muhammad, "Including the believers who have perfect faith, those who are the most moral and compassion towards their families". In another hadith, it says, "You are the best person towards the family. And I am the kindest person to my family. "

According to Suharto (2009), to perpetuate life together, a married couple needs a foundation of feelings of love and affection; so that the household atmosphere becomes peaceful and peaceful. Love is a psychological symbol for women, he wants to give and receive love. Parental love also affects the mental health of their children. Love-love and love-love mean silaturrahim that never broke; which must always be improved and developed.

\section{Ridha and ikhlas}

A married couple should have a personality that describes the acceptance of life as it is. Among these are a ridha (ie peace of heart accepting the provisions of Allah and ikhlas (the act of cleansing and purifying the heart from other than Allah). Both of these qualities are important when they serve their spouse and family.

According to Nyai Zai, in serving our partners we can intend worship that is accompanied by an attitude of ridha and ikhlas. Nyai Zai said thus:
Niat ibadah bagi si istri/pahala besar sudahlah pasti

Jikalah ridha ikhlas hatinya/tahulah istri ke urusannya

(The intention of worship for the wife / great reward is certain

If you are willing to be sincere / know the wife to his affairs)

Ridha is the peace of heart to accept the provisions of God. He will not complain about the bitter fate that befell him. He will be willing to accept reality, gifts, and provisions from God (nrima ing pandum). Rida usually, preceded by the nature of qonaah. Qonaah is an attitude of acceptance and acceptance of the existing reality. This Qonaah is related to psychiatric and selfconcept. He will feel rich even if he is starving physically. He is rich in heart, not greedy. The soul feels free from suffering and delusion that will never happen (Al-Qusyairi, 1988).

Ikhlas is an act of cleansing and purifying the heart of something other than Allah. Signs of ikhas people are: there is no difference when receiving praise and scolding, not looking at the deeds of his deeds, and does not demand merit (Al-Qusyairi, 1998).

Ridha and ikhlas psychologically is the attitude of accepting life as it is. The manifestation of the two characters will make a person's soul calm, peaceful, loving, empathetic, humble, and sincere. He will feel trustworthy, safe, and free from all wishes and false hopes (Shafi, 2004).

\section{Self-presentation}

Candidates or married couples must always create a good impression of their partners; both through appearance, speech, or other attitudes. This character, in social psychology, is known as self-presentation. Self-presentation is a deliberate attempt to act in a certain way that creates a special impression about oneself (Taylor, 2009). Self- presentation, including: 
First, maintain appearance. A married couple must maintain their appearance before their partners. Nyai Zai put it this way:

Para wanita tiap harinya/haruslah taat ke suaminya

Berseri-seri wajah mukanya/menghadap suami tiap tingkahnya

Bermuka masam pada suami/inilah istri yang dimurkai

Murka Allah dan malaikat/akan terpukul yang tidak tobat

(The women every day / must obey their husbands

The radiant face of his face / face her husband every move

Surly to the husband / this is the wrathful wife The wrath of God and angels / will be struck down who do not repent)

Second, keep the words. A married couple must always keep their words to their partners. Nyai Zai writes, every couple should not say bad, make something that the wife dislikes, may not say, may God make you ugly.

Third, maintain attitude. A wife must always be obedient to his wife, but the husband should not make his wife like a slave.

Wajiblah taat pada suami/dalam istimta' harus pahami

Jangan istrinya jadikan budak/dipaksa kerja atau memasak

(Obey to obey the husband / in having fun with the wife must understand

Don't make his wife a slave / forced to work or cook)

A wife should always maintain an attitude towards her husband, by always obeying his orders, as long as he is not told to commit immorality. The husband should not make his wife like a slave. Nyai Zai's opinion is interesting because in 'Uqudul Lujjayn" which is used as a reference in the writing of his work, it says: "Women should know that they are like slaves married to their masters and weak prisoners who are powerless in one's power. Then a woman cannot spend her husband's wealth for anything except with his permission. Even the majority of scholars say that the wife must not spend her own wealth except with the permission of her husband. "Thus, Nyai Zai has reinterpreted the texts of the yellow book, according to the conditions and the current situation.

Fourth, a wife must ask her husband for permission if she wants to travel.

Bila keluar dari rumahnya/tanpa minta idzin ke suaminya

Sejak keluar sampai pulangnya/sama mengutuk makhluk-makhluk-Nya

Walaupun dapat idzin suami/tetap maksiat keluar sendiri

Artinya harus ada mahramnya/mahram nasabnya atau haremnya

Para ulama melarang sungguh/kaum wanita berjalan jauh

Jikalau dekat tidak dilarang/bagi wanita yang bepergian

Misalnya dekat ke tetangganya/hanyalah di sekitar rumahnya

(When leaving her house / without asking her husband for permission

Since coming out until returning / same cursing His creatures

Even though you can get your husband's permission/to keep sinning out on your own

It means that there must be a mahram / mahram nasab or harem

The scholars forbid really / women walk far

If the close is not prohibited / for women traveling 
For example close to his neighbor / just around his house)

The focus of marriage counseling adopted by pesantren circles is directed at the improvement and development of the personality qualities of the candidates and married couples rather than the problems in the marriage itself. Because in their view, if the prospective or married couple have good personalities, then problems in the marriage can be solved. This research is consistent with pesantren- based counseling research, namely attawazun counseling initiated by Arifin (2014) and similar in concept to person-centered counseling (Rogers, 1942; Corey, 2009). The focus of pesantren-style marriage counseling is the personality of a married couple, not the problems that arise in interpersonal relations between husband and wife, as marriage counseling was initiated by Sunarty and Mahmud (2016).

In the view of Nyai Zai, candidates and husband and wife should develop the quality of personality that has knowledge (about some rights and obligations, fiqh of women, and the ability to educate children), grace when suffering from bitter experience (sabar), compassion, acceptance of life for what it is (ridha and ikhlas), and creates a good impression of their partner (self-presentation).

If a married couple has this personality, that personality will radiate in thinking and acting in everyday life. They will achieve peace and tranquility in the household. According to Quraish Shihab, sakinah will be seen in the tranquility of birth - such as the brightness of the expression on the face - and inner calm as gracefully (Shihab, 2006).

\section{Conclusion}

Candidates and married couples in fostering households should develop personalities that have knowledge (about some rights and obligations, fiqh nisa', and the ability to educate children), grace when suffering from bitter experience (sabar), compassion, acceptance of life as it is (ridha and ikhlas), and creates a good impression of their partner (self-presentation). If they have this character, the household will be confident. Sakinah will appear in the physical and spiritual calm of the two couples. The pesantren are more directed towards the quality of personality development. Because the focus of counseling (including marriage counseling) based on pesantren focuses on developing the quality of personality rather than on household problems. If a husband and wife have a good personality then they will be able to solve their household problems as well.

\section{Daftar Pustaka}

Ahmad. 2016. Konseling Pernikahan Berbasis Asmara.Jurnal Konseling Religi,. (Vol.7, No.2): $195-212$

Al-Haddad, A.A., 2005. Sucikan Hati Luruskan Amal: Nasihat-Nasihat Agama Menuju Kesempurnaan Iman (Terjemah anNashaih ad-Diniyyah wa al-Wasaya alIman). Terjemahan Ommi Amin Ababil. Yogyakarta: Mitrapustaka.

Al-Qusyairi, A.Q. 1998. Risalah Qusyairiyah. Terjemahan Umar Faruq. Jakarta: Pustaka Amani

An-Nawawi. Syarh Uqud al-Lujjayn fi Bayan Huqul az- Zawjayn. Surabaya: Dar anNashr al-Mishriyah.

Arifin, S. 2019. Risalah Hati: Trilogi Biografi Nyai Zainiyah As'ad. Situbondo: TA.

Arifin. S. 2018. Pengembangan Desain Konseling Berbasis Pesantren dengan Pendekatan Service- Learning", Jurnal Bimbingan dan Konseling Islam, vol.8. no.2, p.110-132

Arifn, S. 2014. Sang Pelopor: Kisah Tiga Kiai dalam Mengelola Bekas Bajingan. Surabaya: Pena Salsabila 
Atabik. 2015 Dari Konseling Perkawinan Menuju Keluarga Samara. Jurnal Konseling Religi,. (Vol.6, No.1): 107-124

Ayurinanda. 2016. Pelaksanan Konseling Perkawinan yang Sensitif Gender untuk Mencegah Perceraian di Lembaga Rekso Dyah Utami. Jurnal Konseling Religi,. (Vol.7, No.2): 123-145

Basit. 2016. Konseling Perkawinan Perspektif Al-Qur'an. Jurnal Konseling Religi,. (Vol.7, No.2): 175-194

Bisri, M. 2001. Ini Uqud al-Lujjayayn Baru Ini Baru Uqud al-Lujjayn. Dalam Wajah Baru Relasi Suami-Istri Telaah Kitab Uqud al-Lujjayn . Yogyakarta: LKIS.

Corey, G. 2009. Theory and Practice of Counseling and Psychotheraphy, Eighth Edition, Belmont: Thomson Higher Education

Dariyo. 2005. Memahami Bimbingan Konseling dan Terapi Perkawinan untuk Pemecahan Masalah Perkawinan. Jurnal Psikologi. (Vol.3, No.2): 70-78

Forum Kajian Kitab Kuning (FK3). 2001. Wajah Baru Relasi Suami-Istri Telaah Kitab Uqud al-Lujjayn . Yogyakarta: LKIS.

Gadamer, G.H. 2004. Truth and Method, Translation revised by Joel Weinsheimer and Donald G. Marshall. News Yorks: Continuum.

Hasanah. 2016. Konseling Perkawinan (Strategi Penanganan Problem Relasi Keluarga dalam Membangun Keluarga Sakinah. Jurnal Konseling Religi,. (Vol.7, No.2): 77-98

Kim, U dkk. 2010. Indigenous and Cultural Psyichology, Terjemahan Helly Prajitno Soetjipto. Yogyakarta: Pustaka Pelajar

Mas'udi. 2016. Kesetaraan Suami dan Istri dalam Keluarga (Analisis Kesetaraan Pembagian Kerja dalam Keluarga Madura. Jurnal Konseling Religi,. (Vol.7, No.2): 19-34

Mubasyaroh. 2016. Konseling Pra Nikah dalam Mewujudkan Keluarga Bahagia (Studi Pendekatan Humanistik Carl R. Rogers.
Jurnal Konseling Religi,. (Vol.7, No.2): 118

Muhammad, H. 2001. Fiqh Perempuan: Refleksi Kiai atas Wacana Agama dan Gender. Yogyakarta: LKIS.

Riyadi, A. 2013. Bimbingan Konseling Keluarga: Dakwah dalam Membentuk Keluarga Sakinah. Yogyakarta: Penerbit Ombak

Rogers, C.R. 1942. Counseling and Psychotherapy Newer Concepts in Practice. Cambridge: The Ribersibe Press Sakdiah. 2016. Urgensi Adversity Quotient dalam Membangun Keluarga Sakinah. Jurnal Konseling Religi,. (Vol.7, No.2): 99-122

Shafii, M. 2004. Psikoanalisis dan Sufisme (Freedom from the Self: Sufisme, Meditation, and Psychotherapy). Terjemahan. MA Subandi. Yogyakarta: Campus Press

Shihab. 2006. Perempuan: dari Cinta sampai Seks, dari Nikah Mut'ah sampai Nikah Sunnah, dari Bias Lama sampai Bias Baru. Jakarta: Lentera Hati

Soeharto.2009. Konseling Perkawinan, Hubungan Suami- Istri, dan Kesehatan Seksual, serta Implikasinya. Pidato Pengukuhan Guru Besar Bidang Bimbingan dan Konseling, 26 Pebruari 2009 Universitas Sebelas Maret Surakarta.

Sunarty, K \& Mahmud, A. 2016. Konseling Perkawinan dan Keluarga. Makasar: Badan Penerbit UNM

Taylor, S.E dkk, 2009, Psikologi Sosial Edisi Kedua Belas, terjemahan, Jakarta: Kencana Prenada Media Group

Wahid, A. 2007. Menggerakkan Tradisi: EsaiEsai Pesantren. Yogyakarta: LkiS

Zaini. 2015. Membentuk Keluarga Sakinah melalui Konseling Perkawinan. Jurnal Konseling Religi,. (Vol.6, No.1): 89-105. 